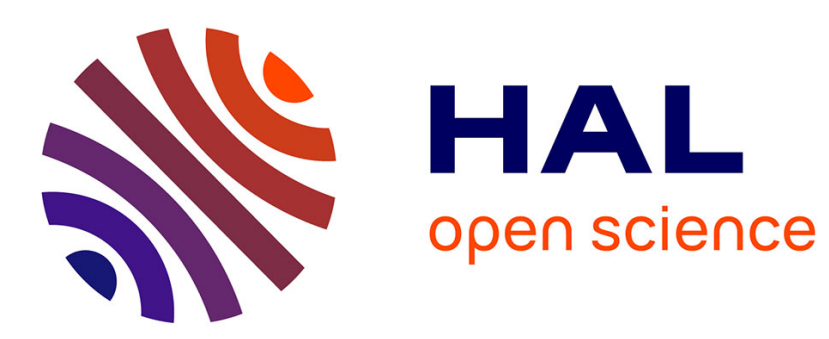

\title{
Internal Friction in Fe-Co-Ni-Ti Shape Memory Alloys
}

\author{
V. Chernenko, V. Kokorin, I. Vitenko, S. Bugaychuk
}

\section{To cite this version:}

V. Chernenko, V. Kokorin, I. Vitenko, S. Bugaychuk. Internal Friction in Fe-Co-Ni-Ti Shape Memory Alloys. Journal de Physique IV Proceedings, 1995, 05 (C8), pp.C8-481-C8-483. 10.1051/jp4:1995873 . jpa-00254122

\section{HAL Id: jpa-00254122 https://hal.science/jpa-00254122}

Submitted on 1 Jan 1995

HAL is a multi-disciplinary open access archive for the deposit and dissemination of scientific research documents, whether they are published or not. The documents may come from teaching and research institutions in France or abroad, or from public or private research centers.
L'archive ouverte pluridisciplinaire HAL, est destinée au dépôt et à la diffusion de documents scientifiques de niveau recherche, publiés ou non, émanant des établissements d'enseignement et de recherche français ou étrangers, des laboratoires publics ou privés. 


\title{
Internal Friction in Fe-Co-Ni-Ti Shape Memory Alloys
}

\author{
V.A. Chernenko, V.V. Kokorin, I.N. Vitenko and S.N. Bugaychuk
}

Institute of Metal Physics, Kiev 252680, Ukraine

\begin{abstract}
The anomalies of the temperature dependences of the logarithmic decrement and eigen frequency of the free damped vibrations for $\mathrm{Fe}-\mathrm{Co}-\mathrm{Ni}-\mathrm{Ti}$ shape memory alloys were first found in the vicinity of the reverse $\alpha-\gamma$ martensitic transformation. It was shown the damping capacity in the alloys investigated is comparable with that for TiNi based alloys.
\end{abstract}

\section{INTRODUCTION}

Aging Fe-Co-Ni-Ti alloys are the new perspective shape memory materials (SMM) [1]. Irreversible martensitic $\gamma-\alpha$ transformation can be modified into thermoelastic one by a special thermomechanical treatment giving rise to the characteristics which are intrinsic to the martensitic transformations (MT's) in TiNi- and $\mathrm{Cu}$ - based alloys. In opposite to the traditional SMM usually $\mathrm{Fe}-\mathrm{Co}-\mathrm{Ni}$-Ti alloys are ferromagnets with invar characteristics and provide higher level of the recovery stresses. Intense investigations of these alloys were performed last few years [2-4], but the attention to their damping behaviour was not paid.

In present study the internal friction (IF) in Fe-Co-Ni-Ti alloys was examined in order to have the initial information about their damping capability.

\section{EXPERIMENTAL PROCEDURE}

Three Fe-Co-Ni-Ti alloys with the chemical composition given in Table 1 were chosen in order to obtain SMM with the values of the characteristic temperatures of MT which can be compared with those for the binary nearly equiatomic TiNi alloys.

Table 1: Composition of the alloys investigated (wt.\%), thermal treatment modes and characteristic temperatures of MT

\begin{tabular}{|c|c|c|c|c|c|c|c|c|c|}
\hline Alloy & Co & $\mathrm{Ni}$ & $\mathrm{Ti}$ & $\mathrm{Fe}$ & Thermal treatment mode & \multicolumn{4}{|c|}{$\begin{array}{c}\text { Characteristic temperatures } \\
\text { of } \mathrm{MT},{ }^{\circ} \mathrm{C} \\
\end{array}$} \\
\hline & & & & & & $\mathrm{M}_{\mathrm{s}}$ & $\mathrm{M}_{\mathrm{f}}$ & $\mathrm{A}_{\mathrm{s}}$ & $\mathbf{A}_{f}$ \\
\hline 1 & 34.3 & 19.0 & 8.5 & Bal. & Quench. $+650^{\circ} \mathrm{C}, 0.5 \mathrm{~h}$ & 23 & -15 & 32 & 85 \\
\hline 2 & 35.1 & 18.4 & 8.4 & Bal. & Quench $+650^{\circ} \mathrm{C}, 3 \mathrm{~h}$ & 55 & -2 & 70 & 140 \\
\hline 3 & 27.1 & 23.4 & 5.8 & Bal. & Quench $+650^{\circ} \mathrm{C}, 0.5 \mathrm{~h}$ & -10 & -40 & 40 & 130 \\
\hline
\end{tabular}


The alloys were melted by induction method, cast into copper mold and hot rolled into the bars. The bars were water quenched from $1100^{\circ} \mathrm{C}$ and rolled at room temperature into the wire with $1 \mathrm{~mm}$ diameter. The wire was vacuum annealed at $1100^{\circ} \mathrm{C}$ for $8 \mathrm{~h}$., subsequent water quenched from $1100^{\circ} \mathrm{C}$ and aged at $650^{\circ}$ $\mathrm{C}$ in salt bath for time periods shown in Table 1. The internal friction measurements have been performed by the method of the free damped vibrations of the wire-like specimens with a length of $110 \mathrm{~mm}$ using inverted torsion pendulum machine. The temperature dependences of the logarithmic decrement $(\delta)$ were measured at heating-cooling rate of $2.5^{\circ} \mathrm{C} / \mathrm{min}$ in the temperature interval $20-450^{\circ} \mathrm{C}$ in a vacuum of $10^{-3}$ $\mathrm{Pa}$ at a frequency about $2 \mathrm{~Hz}$ and oscillation amplitude about $10^{-6}$. Simultaneously, the change the oscillation eigen frequency $(f)$ was detected. Characteristic temperatures of MT were determined by the low field magnetic permeability $(\mu)$ vs, temperature plots. The microstructure of the specimens was observed in an optical microscope.

\section{RESULTS AND DISCUSSION}

The transformation behaviour of an alloy 2 is shown in Fig.1 as a typical example. Characteristic temperatures are taken as shown in Fig. 1 by arrows and listed in Table 1. From Fig. 1 it can be deduced

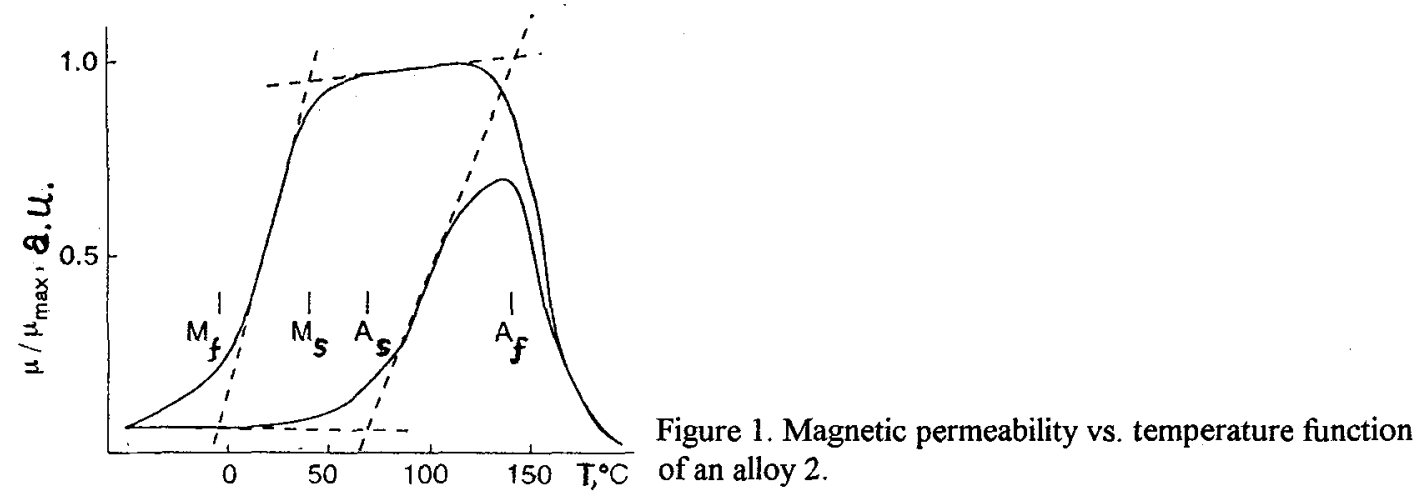

that austenite in the alloys studied is a ferromagnet and in case of an alloy 2 the Curie point is equal to about $150^{\circ} \mathrm{C}$. Optical micrographs confirmed the thin-plate morphology of the martensite in these alloys. The mobile interfaces can effectively dissipate the elastic vibrations. In other words one could expect the high level of IF in the transformation region and in martensite in these alloys.

The temperature spectrum of $\delta$ and $f$ during the reverse $\alpha-\gamma$ transformation for the alloy 1 preliminarily cooled in liquid nitrogen is presented in Fig. 2 . It is worth noting the IF results indicated the similar behaviour for all alloys studied here. So, experimental runs $\delta(T)$ and $f(T)$ are displayed only for alloy 1. Inspection of Fig. 2 gives typical for SMM [5,6] internal friction and frequency behaviour during

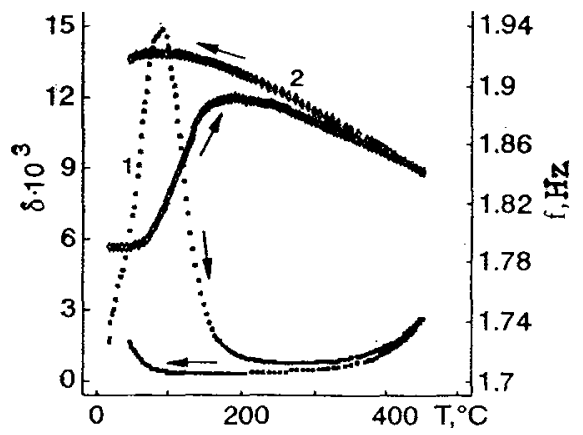

Figure 2: (1) Logarithmic decrement, (2)

Frequency of the free vibrations for the alloy 1 . 
MT, which means that a maximum of IF corresponding to a minimum of frequency is detected in $\alpha-\gamma$ transformatin region. In accordance with the temperature hysteresis of $\gamma-\alpha$ transformation the upward curvature of $\delta(T)$ dependence near the start temperature of the forward MT is observed ( Fig. 2). Increasing of $\delta$ at about $400{ }^{\circ} \mathrm{C}$ is likely due to the damping at the grain boundaries [7]. The peak value of IF at MT appeared to be comparable with that for the binary TiNi alloys $[8,9]$ and can be attributed mainly to the mobility of the parent-martensite interfaces as well as to the transistory term proportional $\mathrm{T} / \mathrm{f}[10]$. Despite the measurements are not complete ( because of the experimental limitations) according to the data of Fig. 2 the intrinsic part of IF arising from the movement of twin boundaries in martensite seems to be low. Considering this contribution starts to increase at the amplitude value more than $5 \times 10^{-5}$ [5] and due to the inherently high yielding stress of martensite in Fe-Ni-Co-Ti alloys [11] it can be indeed expected that the IF for account of stress-induced twin accomodation will be significant at much higher stress level.

Fig. 2 demonstrates the sharp increase of the shear modulus $\mathrm{G}$ while heating. The ubrupt change values of $\mathrm{G}$ during MT are equal to 15,24 and $34 \%$ for alloys 1,2 and 3, respectively. There is a positive slope on the cooling run of $\mathrm{G}(\mathrm{T})$ near the forward MT which also was observed for the invar Fe-Co-Ni alloys near Curie point. The origin of such behaviour has to be a subject for the further investigations.

\section{Conclusion}

The IF measurements firstly performed with $\mathrm{Fe}-\mathrm{Co}-\mathrm{Ni}$-Ti alloys are the initial step in understanding their damping capacity and elastic moduli behaviour in transformation region which extends in this case over $100{ }^{\circ} \mathrm{C}$ near room temperature. The enhanced level of damping at higher stress amplitudes can be anticipated. More systematic work is in progress to confirm such an idea and to propose modelling description of IF behaviour in $\mathrm{Fe}-\mathrm{Co}-\mathrm{Ni}$ - $\mathrm{Ti}$ alloys.

\section{References}

[1] Kokorin V.V., Martensitic transformations in the inhomogeneous solid solutions (Naukova Dumka, Kiev, 1987), p.166.

[2] Jost N., Mat. Sci. Forum 56-58 (1990) 667-672.

[3] Kokorin V.V., Gunko L. P and Shevchenko O.M., Scr. Met. et Mat. 28 (1993) 35-40.

[4] Maki T., Furutani S. and Tamura I., ISIJ International, 29(1989) 438- 445.

[5] Van Humbeeck J., "Internal friction in shape memory alloys", 9-th Int. Conf. on Int. Friction and Ultrasonic Attenuation, Beijing, China, July 17-20, 1989, Ed. T. S. Ke, pp. 337-344.

[6] Lin H.C., Wu S.K. and Chang Y.C., "Damping characteristics of TiNi - based shape memory alloys", Int. Symp. on Shape Memory Materials, SMM-94, Beijing, China, Sept. 25-28, 1994, Ed. Chu Y., Tu H., pp. 205-209.

[7] Wasilevski R.J., Trans. AMME, 233 (1965) 1691-1693.

[8] Zhu J. S., Schaller R. and Benoit W., Phys. stat. sol. (a), 108(1988) 613-618.

[9] Hasiguti R.R. and Iwasaki K., J. Appl. Phys. 39 (1968) 2182-2186.

[10] Bidaux J.E., Schaller R. and Benoit W., Acta Met. 37(1989) 803-811.

[11] Kokorin V.V., Samsonov Yu.I., Chernenko V.A., Shevchenko O.M., Phys. Met. Metall. 67(1989)

202-204. 